\title{
Kroppens tekster - selvskading i skjønnlitteratur
}

\begin{abstract}
Sammendrag
Selvskadende atferd er beskrevet i skjønnlitterære tekster i et tidsspenn på nærmere 2500 år. I denne artikkelen gis det eksempler på selvkvestelse og selvstraff fra Sofokles tragediediktning frem til norsk litteratur fra siste bokhøst. Oppmerksomheten vies særlig to forfattere, den østerrikske nobelprisvinneren Elfriede Jelinek og den norske forfatteren Karl Ove Knausgård. Hos Jelinek relateres selvskadende atferd til selvhevdelses- og autonomitematikk i en familiekontekst, mens Knausgård tydeliggjør skammens rolle som en drivkraft for selvskadende atferd.
\end{abstract}

\section{Finn Skårderud}

finns@online.no

Avdeling for helse- og sosialfag

Høgskolen i Lillehammer

2626 Lillehammer

Det står ikke mye om selvskadende atferd i verdenslitteraturen, men den er til stede. I det følgende presenteres noen eksempler som forhåpentligvis kan tydeliggjøre mangfoldet i selvskading som fenomen. Skjønnlitteraturens fortrinn er ofte at den skriver fra «innsiden», fra en dedikert subjektivitet, mens psykiatri som fag ofte forholder seg til ytre realiteter som symptomer og atferd. Det første litterære eksemplet i denne teksten er hentet fra den greske antikken, mens resten er fra moderne litteratur.

\section{Sofokles og skylden}

En av litteraturens urscener handler om å kveste seg selv. Kong Oidipus (1) regnes som den atenske tragediedikteren Sofokles' (ca. 496-406 f. Kr) beste drama, og Aristoteles bruker mange eksempler fra dette stykket når han skal beskrive den gode tragedien i Om diktekunsten (2). Orakelet i Delfi hadde forkynt at kong Laios ville få en sønn som skulle drepe sin far og gifte seg med sin mor. Da dronning Iokaste fødte en sønn, ba de en gjeter sette ham ut på fjellet for å dø. Gjeteren fikk medynk med gutten og ga ham til en annen gjeter, som brakte ham til det barnløse kongeparet i Korint. Spådommen går i oppfyllelse. $\mathrm{Og}$ når Oidipus innser dette, stikker han ut begge sine øyne:

«og skrek at aldri mer hans øyne skulle se hva ondt han led, ei se hva ondt han hadde gjort,

men se i mørket dem han ikke burde se og ikke kjenne dem han ønsket helst å se» (1).

En sentral psykologisk tematikk er altså skyld. Selvblindingen er en konkret kroppsmetafor for å stenge ute Oidipus’ plutselige innsikt om farsdrapet og den incestuøse relasjonen til moren. $\mathrm{Og}$ når Sigmund Freud senere bruker tragedien som kilde til å beskrive en «ødipal» konflikt, er skyld en sentral affektiv komponent.

\section{Affektregulering hos Mykle}

I sine til sammen fire romaner utforsker Agnar Mykle den unge mannens sinn. Hovedpersonen er i en situasjon der han orienterer seg bort fra de småborgerlige verdiene som preget oppveksten, samtidig som han ennå ikke har etablert et sikkert fotfeste i livet. Den følsomme unge mannen står meget ustøtt i sitt eget liv, og ikke minst har han et splittet forhold til kvinner. I Sangen om den røde rubin fra 1956 sitter Ask Burlefot og er urolig før han skal få kvinnebesøk:

«Om formiddagen satt han og stakk seg $i$ håndflaten med en lommekniv, det var en manøvre for å avlede tankene.» (3).

Det er langt fra denne tekstens hensikt å skulle psykiatrisere litterære figurer eller pådytte Mykles Ask Burlefot nevroser. Men denne litterære skikkelsen er egnet til å illustrere den mulige følelsesreguleringen det er å påføre seg selv kroppslig smerte. I sitatet påpekes det eksplisitt at det å påføre seg fysisk smerte kan avlede en indre smerte eller uro. Hvem er han? På mesterlig vis portretterer Mykle en hovedperson som kommer til storbyen med en følelsesmessig sårbarhet knyttet til kompliserte relasjoner både til moren og faren.

«Han var en ytterst fortapt sønn, som med oppbydelsen av de største krefter hadde reist seg og nektet å være fortapt.» (3).

Ask Burlefot er et lidenskapelig menneske, så vel i forhold til politikk som seksualitet.
Han styres veldig av ungdommelighetens sterke følelser og lidenskaper. Men han kjenner også ungdommens usikkerhet.

«En ung mann, det nakne og følsomme hjerte (å, som den skjelvende huden i flanken på en fullblodshest), i alle himmelrosens retninger går hans lengsler, den unge mannens sjel er vibrerende som nålen $i$ et kompass (men uten dens retningsfinnende evne).» (3).

Beskrivelsene av hans uro og den selvskadende handlingen er i overensstemmelse med aktuelle definisjoner av selvskading som kroppshandlinger for å regulere vanskelige følelser. Sutton definerer den selvskaden vi hyppig møter i terapeutiske rom i dag på følgende vis: «Selvskading følger en tvang eller impuls til å påføre fysisk skade på egen kropp, motivert av behovet for å mestre psykologisk smerte eller for å gjenvinne følelsesmessig balanse. Handlingene er vanligvis utført uten suicidale, seksuelle eller dekorative hensikter.» $(4,5)$

Stålesen og posttraumatisk smerte Selvskading blir mer utdypende beskrevet og årsaksforklart i bergensforfatteren Gunnar Staalesens kriminalroman av fjoråret, Kalde hjerter (6). Han har empirisk støtte når han lar den selvskadende kvinnen være en som har vokst opp i et hjem preget av omsorgssvikt, rus og seksuelle overgrep. I både klinisk og vitenskapelig litteratur legges det vekt på at det særlig er oppveksterfaringer innenfor familiekonteksten som er forbundet med utvikling av selvskadende atferd som ungdom og voksen. Det vises til fysiske og seksuelle overgrep, omsorgssvikt, tap og separasjon samt den affektive kvaliteten på tilknytningsbåndene (6). Utover dette kommer individuelle risikofaktorer i form av sensitivitet for følelsesmessige stimuli.

Tre barn er ofre for foreldrenes vanskjøtsel. Den ene har klart seg langt bedre enn de to andre, lever et tilsynelatende ordnet liv med arbeid i et forsikringsselskap. Det er hun som avsløres i en intim scene:

«Men det var ikke brystene hun prøvde å skjule. Ikke kjønnet. Det var armene.» «Armene! Ikke nålemerker?»

«Nålemerker. Det var arr. Begge armene hennes var fulle av arr. Lange, svulmende arr. Noen av dem med ferske skorper, andre gamle og grodde.»» 
«Men ...»

«Hun hadde skadet seg selv, Varg. Hun hadde skåret seg opp, i årevis!»

«Seg selv?»

«Hun - fortalte det selv. Hun sa: Du skal gå, Nils. Glem denne kvelden. Glem det du så. Dette er min mørke hemmelighet, og når du kjenner til den, kan du aldri komme tilbake igjen.» (6).

Senere i teksten utveksler kvinnen og detektiven Varg Veum tanker om selvskadingens motiver:

\section{«Det var for - å straffe deg selv?»}

Hun trakk på skuldrene. «Jeg vet ikke. Det var bare noe jeg gjorde. Det var jo ingen andre jeg kunne - være slem mot.»

«Men du vet at det er feil. At det ikke er noen som helst grunn til å straffe deg selv for de overgrepene andre har gjort mot deg.»

«Jeg vet det, ja. Men det er ikke så lett å ... Av og til er det bare noe jeg må! Som en slags - rus. Noe som har forgiftet meg, for alltid.» (6).

\section{Simonhjell - Å skade for å omskape}

Det er all grunn til å nevne en nyere norsk diktsamling. Nora Simonhjell er en av våre desidert mest interessante og originale lyrikere. I Slaktarmøte (7) går forfatteren voldsomt, systematisk, grotesk og språklig fascinerende vakkert løs på den egne kroppen. Diktenes jeg-person har innledet et forhold til slakteren og låner hans kniver, bryne og kompetanse. Selvskaden er diktsamlingens sentrale poetiske metafor. Med knivene som metaforens redskaper vil hun forvandle seg selv og finne mer av seg selv og sin egen individualitet.

«eg minnest ansiktet mitt

det dei andre ser som meg

eg kjenner ikkje dette fjeset

eg ser bestemor

eg ser far og mor mi si hake

innestengde

frosne fast i det dei kallar meg

eg prøver å ikkje sjå

ikkje høyre

eg vil bak fjella

gjennom genane» (7)

Hun skjærer, kutter og regelrett flår seg selv. Hun forandrer den fysiske kroppen som for henne symboliserer at hun er definert, formet og styrt av andre. Min lesing av denne høyst urovekkende teksten er at hun må skade seg selv for å skape seg selv. Hun trenger å bli en annen.

\section{Jelinek og den invaderende moren}

$\AA$ hevde sin individualitet er også et sentralt psykologisk tema i Elfriede Jelineks roman Pianolarerinnen (8). Romanen, der selvskading står helt sentralt, er også blitt filmatisert. I møtet med nobelprisvinner Jelineks tekst er det fristende å spørre retorisk: Hva er det med Østerrike? Hun skriver seg inn $i$ en tradisjon av rasende og selvutmeldte forfattere som utagerer litterært, som Thomas Bernhard, Franz Grillparzer, Hermann Broch, Robert Musil og Karl Kraus (9). Det kan se ut som om det finnes en nasjonal psykosomatikk som gir en særegen grobunn for en «mistankens hermeneutikk», der man søker å avsløre spillene i overflaten. Freud og Wittgenstein er fremstående representanter for å avsløre så vel kultur som språk. Freud skrev allerede for hundre år siden om den østerrikske borgerkulturens dobbeltmoral, om benektninger og fortrengninger, og han skapte et psykologisk univers av spennet mellom overflate og dybde.

Jelinek skriver seg inn i en østerriksk litteratur som speiler en dialektikk mellom individuelle historier om å være krenket og en kollektiv følelse av kulturen som en krenker. Hykleri og brutalitet er viktige ingredienser, og Jelineks litteratur er selv brutal i sine avslørende skildringer. Sjokket og provokasjonen er for henne sentrale litterære figurer. Jelinek har selv en lang psykoterapeutisk behandlingshistorie etter at hun første gang som seksåring kom $\mathrm{i}$ behandling hos den østerrikske psykiateren Hans Asperger. Selv har hun beskrevet det som «kriminelt» at moren sendte henne til en rekke terapeuter i stedet for å sende henne ut i gaten for å leke med andre barn. Asperger hevdet at barnet Jelinek hadde en intens indre uro som måtte finne et uttrykk. I noen ungdomsår ble musikken uttrykket. Etter et alvorlig nervesammenbrudd 18 år gammel ble det skrivingen.

Pianolærerinnen Erika Kohut lever i en malign symbiose med sin mor. De har underkastet seg spissborgerlighetens normer om prestasjon og ytelse. Erikas nerver gjorde at hun feilet som konsertmusiker, og hun må nøye seg med å være lærerinne for elever hun forakter. Moren elsker og dyrker sitt barn, men krever også fullstendig kontroll over den voksne datterens liv.

«Barnet er morens avgud, og barnet blir derfor kun avkrevd lave gebyrer: livet sitt. Moren vil selv få lov til å nyttiggjøre seg barnets liv.» (8).

De sover i samme seng, og moren styrer klesvalg, mat og at det ikke skal være menn i datterens liv. Morens kjærlighet er altoppslukende og absolutt ødeleggende. Datteren Erika har vansker med å kjenne og vite hva hun kjenner:

«Erika føler ingenting og har aldri følt noe. Hun er like følelsesløs som en bit takpapp i regnet.

(...)

Erika føler ingenting og kan aldri kjærtegne seg selv. Moren sover ved siden av henne og passer på Erikas hender. Disse hendene skal øve, de skal ikke gli som maur under dynen og krype mot syltetøyglasset. Heller ikke når Erika kutter og stikker seg selv, føler hun noe spesielt. Det er bare synet hun setter i full blomst.» (8).

Erikas fortvilte form for identitet, en måte å merke seg selv på, blir selv å ta kontroll over de skader hun påfører seg. Det er hun som påfører skaden, og det er hun som får blodet til å flyte. Moren er stengt ute og har ikke lenger kontrollen over datteren.

«Lydighet forlanges av moren. Og: den som setter seg selv i fare, omkommer i den, dette rådet gir i hvert fall moren. Når ingen er hjemme, skjærer hun seg med vilje i sitt eget kjøtt. Hun har allerede ventet lenge på øyeblikket når hun kan skjære seg selv usett. ... Dette bladet er ment for HENNES kjøtt. Denne tynne, elegante lille platen av blålig stål, bøyelig, elastisk. HUN setter seg med sprikende ben foran den forstørrende siden av barberspeilet og utfører et snitt som skal forstørre åpningen, døren som fører inn i hennes legeme.» (8).

Jelinek rapporterer fra et desperat univers, der selvskade og fornedrende seksualitet blir konkrete kroppslige metaforer for å kare til seg et minstemål av autonomi i en familierelasjon og i en kulturell situasjon der individet blir strengt kontrollert og definert. Hun jakter etter å utfolde seg på egne premisser. Selvskaden i Jelineks roman Pianolcererinnen kan fortolkes som at hun skader seg selv for å føle seg selv, for så å vite at hun har et selv.

\section{Knausgård og skammen}

Henrik Vankel er jeg-personen i Karl Ove Knausgårds romaner Ute av verden fra 1998 (10) og En tid for alt fra 2004 (11). Knausgård er en skarp psykolog som demonstrerer en imponerende evne til å iaktta. Henrik Vankel er en ung mann som skammer seg intenst. Den sterke skamfølelsen er blitt selve meningsinnholdet i livet hans. Han er insisterende opptatt av sin egen elendighet. Skammen er således selvforsterkende. Henrik går konkret til verks. Han går løs på seg selv med glasskår.

«Jeg kunne ha brukt kniv, men det er noe frastøtende over det, eggen glir motstandsløst inn i huden, smerten er skarp, som om noe blir satt i svingning i meg, umulig å nå, umulig å få tak på. Men glasset fordrer makt, og smerten er jevnere, tydeligere.

Jo: en slags nervøsitet.» (11).

Knausgård gir oss et rått portrett av selvskaden. Det er mange former for selvskading, fra røyking til selvmord. Når vi i psykiatrien snakker om selvskading, sikter vi som beskrevet vanligvis til den gjentatte atferden som ikke er utført i selvmorderisk 
hensikt (4). Dens sedvanlige former er risping, kutting eller lettere brannskader (5). Til forskjell fra fakiren, eller den unge som én gang tester ut en grense, har selvskaderen som regel begrenset kontroll over slik atferd.

«Så kom jeg på hva jeg hadde gjort, og fortvilelsen var kald og ikke til å holde ut. Hvorfor hadde jeg ikke bare sagt nei? Nei til det i meg som ville dette?

Jeg satt lenge i sengen og gråt.

(...)

En trang til mer smerte dukket opp, og jeg sa ikke nei til den til tross for det jeg nettopp hadde tenkt inne på soverommet. Smerten har med uendelighet å gjøre, det har jeg alltid tenkt, ikke den lille, korte smerten, men den smerten som dunker og kverner og holder på.

Suget etter mer, mer, mer.» (11).

Smerten er noe vi vanligvis løper fra. Når den likevel blir oppsøkt, er det fordi den kan ha noe å gi. Smertens fortrinn er at den kan skyve annet til side. Selvskaden er paradoksal i sitt vesen. Smertens paradoksale kvalitet er at den kan være smertelindrende.

«Det som i begynnelsen var klart adskilte spor av smerte, samlet seg etter hvert til én, brennende.» (11).

Selvskadingen kan ha mange motiver. Såret som blør er et konkret og fattbart faktum. Selvskaden er en definert, avgrensbar og synlig skade som kan gi uttrykk til en indre skade som er vanskeligere å definere, avgrense og å fatte. Selvskadingen sier noe om vanskeligheter med å fastholde seg selv som subjekt. Ved selvskade er strategien for å redde seg selv som subjekt nettopp å objektivisere seg selv gjennom sin kropp. Selvskaden kan som beskrevet også være et middel til å avreagere eller avlede utålelig indre uro. Eller det kan være en selvstimulering for å unnslippe følelsen av tomhet, nummenhet og av å føle seg som frakoplet (5).

«Det fantes en motstand i smerten som jeg likte, den måtte overstiges, gang etter gang, og det fantes en rytme, som etter hvert slukte meg opp.» (11).

For atter andre handler det om selvforakten og straffen. De iverksetter straffen i en dom de har felt over seg selv. Ødeleggelsen på utsiden er et forsøk på å skape en enhet mellom indre og ytre. Kanskje vi kan forstå selvskaden. Den er et symptom som sladrer om et problem. Den er også et forsøk på en løsning. Men løsningen er definitivt ikke god nok. Selvskaden kan innlemmes i det vi kaller «skambaserte syndromer» (12). Andre eksempler på slike er rusmisbruk og spiseforstyrrelser. Det er fenomener hvor skamfølelsen er en viktig del av grunnlaget for den symptomatiske atferden, og hvor atferden så fører til mer skam. Det blir mer av det samme.

«Om kvelden, etter å ha sittet og lest i noen timer, skar jeg opp ansiktet på samme måte. Jeg vet ikke helt hvorfor. Det hadde et sug i seg. Et stort sug i seg. Men jeg hadde gjort det før, og visste at skammen som kom til å følge, nesten ikke ville være til å bære. Det gjaldt å legge så mye tid som mulig mellom hendelsen og skammen. Derfor la jeg meg til å sove. Men det gikk naturligvis ikke.» (11).

\section{Symbolisering av smerten}

Vi møtes gjennom språket. Språket er en symbolisering av erfaringer og indre liv. Men språket kan være fullt av mangler, slik at det for noen kan være lettere å holde frem en konkret hud av celler og vev. Selvskaden vitner, bokstavelig talt, om en skade på selvet. Den viser til en manglende evne til å symbolisere følelser og levd liv. Selvskading er, i likhet med spiseforstyrrelser, beskrevet hos personer som har vansker med å regulere indre spenninger og å iden- tifisere og verbalt uttrykke sine følelser. Samtalebehandlingenes mål og metode er å forsøke å fremme symbolisering, ved å løfte følelser som er bundet i destruktive kroppspraksiser til et levende språk om den menneskelige tilstanden.

Forfatteren er fri til å dikte og overdrive. Selvskading i skjønnlitteratur kan dels leses som realistiske skildringer av slike fenomener, som et forsøk på å håndtere vanskelige liv og følelser. Slik kan de hjelpe legen og klinikeren til et innenfraperspektiv på denne atferden. Dels kan de litterære tekstende leses som en utfordrende og provoserende kroppsmetaforikk, som hos lyrikeren Nora Simonhjell, med hensikt å tydeliggjøre de psykologiske mangler og konflikter som ligger bak. Uansett kan slike skjønnlitterære skildringer bidra til rikere forståelse av selvskading som komplekse fenomener og til å fremme vår felles symbolisering av det følelsesliv som utageres gjennom kroppslig atferd.

Oppgitte interessekonflikter: Ingen

\section{Litteratur}

1. Sofokles. Kong Oidipus. Oslo: Gyldendal, 2004

2. Aristoteles. Om diktekunsten. Oslo: Cappelen Akademisk, 2004

3. Mykle A. Sangen om den røde rubin (1956). Oslo: Gyldendal, 1994.

4. Sutton J. Healing the hurt within. Understand selfinjury and self-harm, and heal the emotional wounds. Oxford: How to Books Ltd, 2007

5. Sommerfeldt B, Skårderud F. Hva er selvskading? Tidsskr Nor Legeforen 2009; 129: 754-8.

6. Staalesen G. Kalde hjerter. Oslo: Gyldendal, 2008.

7. Simonhjell N. Slaktarmøte. Oslo: Tiden, 1998.

8. Jelinek E. Pianolærerinnen. Oslo: Gyldendal, 2005

9. Skårderud F. Uro. En reise i det moderne selvet. Oslo: Aschehoug, 1998.

10. Knausgård KO Ute av verden Oslo: Oktober 1998.

11. Knausgård, KO. En tid for alt Oslo: Oktober, 2004.

12. Kaufman G. The psychology of shame. Theory and treatment of shame-based syndromes. New York, NY: Springer, 1989

Manuskriptet ble mottatt 3.11.2008 og godkjent 22.2. 2009. Medisinsk redaktør Anne Gitte Hertzberg. 